\title{
$\mathrm{KrF}$ エキシマガスにおける放電開始特性の定量化
}

正員 斉 藤 善 夫 (三菱電機)
正員 佐 藤 行 雄 (三菱電機)
正員 殖 栗 成 夫 (三菱電機)

\section{Quantification of the Breakdown Characteristics in KrF Excimer Gas}

Yoshio Saitoh, Member, Yukio Sato, Member, Shigeo Ueguri, Member (Mitsubishi Electric Corporation)

The analysis of the breakdown characteristics in $\mathrm{KrF}$ excimer gas with a charge transfer circuit is made. We calculate the breakdown characteristics assuming a zero-dimensional uniform plasma in the prebreakdown region. And we measured them in the range of $0.3 \sim 6.0 \% \mathrm{Kr}, 0.1 \sim 0.25 \% \mathrm{~F}_{2}$ and $0.24 \sim 0.36 \mathrm{MPa}$ total pressure.

The measured and calculated breakdown characteristics are in a good agreement, then we explain principal factors controlling the breakdown. The results are as follows, (1) the electron multiplication process in the prebreakdown region is mainly controlled by the direct ionization of $\mathrm{Kr}$ and dissociative attachment of $\mathrm{F}_{2}$, (2) the breakdown voltage has a minimum value with the variation of $\mathrm{Kr}$ partial pressure, and this characteristic corresponds to the variation of the ionization collision frequency, (3) the breakdown voltage increases with $\mathrm{F}_{2}$ partial pressure, and this is caused by the reduction of the electron multiplication due to the dissociative attachment, ( 4 ) the breakdown voltage increases with the total pressure, and this is caused by the reduction of the electron multiplication due to the decrease of the reduced electric field $E / N$.

キーワード : 放電開始特性, 電子増倍, 電離衝突, 解離性付着衝突, エキシマレーザ, 容量移行型回路

\section{1. まえがき}

エキシマレーザはパルスごとに主電極間の絶緑破壊過程 を繰り返すため, 放電開始電圧の定量が装置設計上の重要 な課題となる。例光ば通常用いられる容量移行型回路は, 一次ループから二次ループヘのパルス圧縮機能をもつ。本 回路方式では, 主放電の放電開始現象が二次ループのスイ ッチ動作をかねるため，二次コンデンサへの移行エネルギ 一は放電開始電圧で規定される。また放電開始電圧は，電 極部が経験するほぼ最大の電圧であり，装置の絶縁設計の 面からも放電開始電圧の制御を目的とした放電機構の解明 が必要とされる。

現在，エキシマレーザにおける放電開始電圧のガス組 成, 全圧力, 電極間依存性は, 実験結果よりほぼ推定され うるようになっている。しかし，放電物理の面からエキシ マレーザの放電開始機構を解析した報告(1)-(5) は少なく， 放電開始機構には不明な点が多いのが現状である。

エキシマレーザの放電開始特性は，主放電に先立方行わ れる予備電離により制御されている。本論文では, 予備電 離で制御された放電開始過程を零次元プラズマモデ ル(6) (13)により定量化し, 放電抵抗の減少に伴亏電極間電
圧の変化を検出することによる放電開始特性の定量化を試 みる。また予備電離で制御された放電開始特性に対し, 衝 突電離による電子増倍が支配的な要因であることを示す。 更に放電開始特性のガス分圧, 全圧力依存性の定量化抢上 びそれらを支配する放電開始機構について報告する。

\section{2. 放電開始特性の定量化}

〈2・1〉 エキシマレーザ放電のモデル化＼cjkstart本論文では, 沿面コロナ予備電離方式による容量移行型回路のエキシマ レーザ装置を用いて解析および測定を行った。放電部は Chang 型構造 ${ }^{(14)}$ の陽極と多数の開孔を有する平板開孔構 造の陰極から構成されている(15)。主放電に先立ち開孔部 に沿面コロナ放電を発生させ，ここから発生する紫外光に より放電領域を予備電離する。

解析に用いた等価回路を図 1 に, 回路定数扔よび放電形 状を表 1 に示す。ここで，L1は一次ループの構造的イン ダクタンスとサイラトロンスイッチに内在するインダクタ ンスの和, $R_{1}$ は同抵抗, $L_{2}$ は二次ループの構造的インダ クタンス, $R_{d}$ は放電抵抗である。また解析対象とした放 電条件は, 電極間隔 $1.2 \mathrm{~cm}, \mathrm{Kr}$ 分圧率 $0.1 \sim 6.0 \%, \mathrm{~F}_{2}$ 分压率 $0.1 \sim 0.4 \%$, 全圧力 $P_{0}=0.20 \sim 0.41 \mathrm{MPa}$, 緩衝力゙ 
図 1 容量移行型回路の等価回路

Fig. 1. Equivalent circuit of the charge transfer circuit.

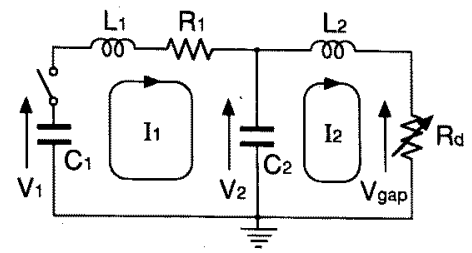

表 1 回路定数と放電形状

Table 1. Circuit parameters and the dimension of the discharge.

\begin{tabular}{|c|c|}
\hline $\begin{array}{l}\mathrm{C}_{1} / \mathrm{C}_{2} \\
\mathrm{~L}_{1} / \mathrm{L}_{2} \\
\mathrm{R}_{1}\end{array}$ & $\begin{array}{c}12 / 12 \mathrm{nF} \\
270 / 8 \mathrm{nH} \\
2.8 \Omega\end{array}$ \\
\hline 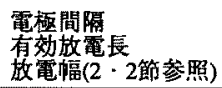 & $\begin{array}{l}\mathrm{d}=1.2 \mathrm{~cm} \\
\mathrm{~L}=40 \mathrm{~cm} \\
\mathrm{~W}=0.5 \mathrm{~cm}\end{array}$ \\
\hline
\end{tabular}

ス $\mathrm{Ne}$ である。

本解析では, 回路方程式, ボルツマン方程式, レート方 程式を連立させることにより放電開始特性を定量化し た ${ }^{(6)-(9)}$ 。励起放電は全計算時間中零次元均質プラズマを 仮定し, ストリーマの発生, 電荷の極在化, アーク転移な どは考慮していない。

ボルツマン方程式は, 2 項近似展開による定常モデルを 用いた。これは, エキシマレーザ放電では気圧が数気圧の ため, 電子の運動量緩和時間は $10 \mathrm{ps}$ 程度, エネルギー緩 和時間は ns 程度となるためにほ浽当と考えられる 放電開始前領域では，空間電荷密度分布が顕著でなく陰極 シースが形成されていないため(17), 放電場の電界 $E$ は電 極間電圧 $V_{\text {gap }}$ から直接に算出した $\left(E=V_{\mathrm{gap}} / d\right)$ 。

回路方程式における放電抵抗は次式により算出した。

$R_{d}=d /\left(e N_{e} S \mu_{e}\right)$

ここに, $R_{d}$ : 放電抵抗, $e, N_{e}$ : 電子電荷, 数密度,

$S$ : 電界に垂直な放電断面積, $\mu_{e}$ : 電子移動度

電子数密度 $N_{e}$ はレート方程式から, 電子移動度 $\mu_{e}$ は ボルツマン方程式からそれぞれ計算される。また放電断面 積 $S$ は, 表 1 の有効放電長 $L$ と放電幅 $W(\langle 2 \cdot 2\rangle$ 節参 照）の積とし一定值を仮定した。

レート方程式では, 中性原子, 励起原子, イオン, 光子 执よびそれらの反応式を考慮した(6)(7)(10) -(12)。ここで, 電 子についてのレート方程式は次式となる。

$$
\begin{aligned}
d N_{e} / d t= & \sum k_{e i} N_{j} N_{e}+\sum k_{p e} N_{i} N_{j} \\
& +\sum c \sigma_{j} N_{j} N_{p h}-\sum k_{a} N_{j} N_{e}
\end{aligned}
$$

ここに, $N$ : 粒子数密度, 添字 $e, p h$ : 電子, 光 子を表す, 添字 $i, j$ : 各反応に関与する準位を表 す, $k$ : 反応速度定数, 添字 $e i, p e, a$ : 電子衝突

電離, Penning 電離, 解離性電子付着を表す, $c$ : 光速, $\sigma:$ 光電離断面積

(2) 式右辺第 1 項は電子衝突による直接执よび累積電 離, 第 2 項は Penning 電離, 第 3 項は光電離, 第 4 項は
表 2 電離, 付着反応

Table 2. Reaction of the ionization and the

\begin{tabular}{|c|c|c|c|}
\hline \multicolumn{4}{|l|}{ 茴接電離 } \\
\hline (1) $\mathrm{Ne}$ & \multicolumn{3}{|l|}{$+\mathrm{e} \rightarrow \mathrm{Ne}^{+}+2 \mathrm{e}$} \\
\hline [2] $\mathrm{KT}$ & \multicolumn{3}{|l|}{$+\mathrm{e} \rightarrow \mathrm{Kr}^{+}+2 \mathrm{e}$} \\
\hline$[3] F_{2}(0)$ & \multicolumn{3}{|l|}{$+\mathrm{e} \rightarrow \mathrm{F}_{2}++2 \mathrm{e}$} \\
\hline 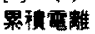 & \multicolumn{3}{|c|}{$+e \rightarrow \mathrm{F}_{2}^{+}+2 e$} \\
\hline [4] Ne* & \multicolumn{3}{|c|}{$+\mathrm{e} \rightarrow \mathrm{Ne}^{+}+2 \mathrm{e}$} \\
\hline$[5] \mathrm{Ne}_{2}^{*}$ & \multicolumn{3}{|c|}{$+\mathrm{e} \rightarrow \mathrm{Ne}^{+}+2 \mathrm{e}$} \\
\hline [6] $\mathrm{Kr}^{*}$ & \multicolumn{3}{|c|}{$+\mathrm{e} \rightarrow \mathrm{Kr}^{+}+2 \mathrm{e}$} \\
\hline $171 \mathrm{Kr} *$ & \multicolumn{3}{|c|}{$+\mathrm{e} \rightarrow \mathrm{Kr}_{2}{ }^{+}+2 \mathrm{e}$} \\
\hline$[8] F_{2}(V)$ & \multicolumn{3}{|c|}{$+\mathrm{e} \rightarrow \mathrm{F}_{2}^{+}+2 \mathrm{e}$} \\
\hline Penning & \multicolumn{3}{|c|}{ 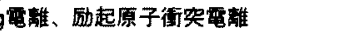 } \\
\hline [9] $\mathrm{Ne}^{*}$ & \multicolumn{3}{|c|}{$+\mathrm{Kr} \rightarrow \mathrm{Kr}^{+}+\mathrm{Ne}+\mathrm{e}$} \\
\hline [10] $\mathrm{Ne}^{*}$ & \multicolumn{3}{|c|}{$+\mathrm{Kr} \rightarrow \mathrm{NeKr}^{+}+\mathrm{e}$} \\
\hline [11] $\mathrm{Ne}^{*}$ * & \multicolumn{3}{|c|}{$+\mathrm{Kr}^{*} \rightarrow \mathrm{Kr}^{+}+2 \mathrm{Ne}+\mathrm{e}$} \\
\hline [12] Ne2* & \multicolumn{3}{|c|}{$+\mathrm{Kr} \rightarrow \mathrm{NeKr}^{+}+\mathrm{Ne}+\mathrm{e}$} \\
\hline [13] $\mathrm{Ne}^{*}$ & \multicolumn{3}{|c|}{$+\mathrm{Ne}^{*} \rightarrow \mathrm{Ne}^{+}+\mathrm{Ne}+\mathrm{e}$} \\
\hline [14] $\mathrm{Kr}^{*}$ & \multicolumn{3}{|c|}{$+\mathrm{Kr}^{*} \rightarrow \mathrm{Kr}^{+}+\mathrm{Kr}+\mathrm{e}$} \\
\hline $\begin{array}{l}\text { [15] } \mathrm{Kr}^{*} \\
\text { 光電離 }\end{array}$ & \multicolumn{3}{|c|}{$+\mathrm{Kr}^{*} \rightarrow \mathrm{Kr}^{+}+2 \mathrm{Kr}+\mathrm{e}$} \\
\hline$[16] \mathrm{Ne}^{*}$ & \multicolumn{3}{|c|}{$+\mathrm{ph} \rightarrow \mathrm{Ne}^{+}+\mathrm{e}$} \\
\hline$[17] \mathrm{Kr}^{*}$ & \multicolumn{3}{|c|}{$\begin{array}{l}+\mathrm{ph} \rightarrow \mathrm{Ne}^{+}+\mathrm{e} \\
+\mathrm{ph} \rightarrow \mathrm{Kr}^{+}+\mathrm{e}\end{array}$} \\
\hline$[18] \mathrm{F}^{-}$ & \multicolumn{3}{|c|}{$+\mathrm{ph} \rightarrow \mathrm{F}+\mathrm{e}$} \\
\hline 解離性付 & \multicolumn{3}{|l|}{ 盖、解離性再結合 } \\
\hline$[19] F_{2}(0)$ & \multicolumn{3}{|c|}{$+\mathrm{e} \rightarrow \mathrm{F}^{-}+\mathrm{F}$} \\
\hline$[20] \mathrm{F}_{2}(\mathrm{~V})$ & \\
\hline [21] $\mathrm{KrF}^{*}$ & \multicolumn{2}{|c|}{$\begin{array}{l}+\mathrm{e} \rightarrow \mathrm{F}^{-}+\mathrm{F} \\
+\mathrm{e} \rightarrow \mathrm{Kr}+\mathrm{F}^{-}\end{array}$} & $+\mathrm{e} \rightarrow \mathrm{Kr}+\mathrm{F}^{-}$ \\
\hline$[22] \mathrm{Ne}_{2}{ }^{+}$ & \multicolumn{3}{|c|}{$+\mathrm{e} \rightarrow \mathrm{Ne}^{*}+\mathrm{Ne}$} \\
\hline$[23] \mathrm{Kr}^{+}$ & \\
\hline$[24] \mathrm{NeKr}$ & \multicolumn{3}{|c|}{$\begin{aligned}+\mathrm{e} & \rightarrow \mathrm{Kr}^{*}+\mathrm{Kr} \\
++\mathrm{e} & \rightarrow \mathrm{Kr}^{*}+\mathrm{Ne}\end{aligned}$} \\
\hline
\end{tabular}
attachment.

解離性電子付着を表す。本解析で考慮した電離, 電子付着 反応を表 2 に示す。表 2 中 $\mathrm{Ne}^{*}, \mathrm{Kr}^{*}$ は準安定準位, $\mathrm{F}_{2}(V)$ は $V=1 ， 2 ， 3$ の振動励起準位, ph は光子を示す。 また予備電離による初期電子数密度 $N_{e 0}$ は $1.0 \times 10^{6} \mathrm{~cm}^{-3}$ の一定值を仮定した $(\langle 2 \cdot 2\rangle$ 節参照)。

本諭文では, 陰極からの二次電子放出 ${ }^{(18)}$ は考慮しなか つた。これは放電開始時間が $200 \mathrm{~ns}$ 以下の領域であり， イオンによる二次電子放出はほとんど期待されないこ と(5)，光子による電子放出は放電開始前には影響しないと 推定されること(17) を根拠とする。

回路方程式とレート方程式は時間に関する微分方程式で ありこれらの計算中に電極間電圧 $V_{\mathrm{gap}}$ が $0.5 \%$ 変化す るごとにボルツマン方程式を呼び出し, 反応速度定数と電 子移動度を再計算している。ボルツマン方程式に用いた衝 突断面積は文献 (19)〜 (26), レート方程式に用いた反応係 数は文献 (6)，（7)，(10)〜 (12) を参照した。

〈2・2〉放電開始特性の定量法 本解析による各部の 電圧, 電流, 電子数密度, 放電抵抗の時間変化学図 2 に示 す。 $t=0$ で一次ループのスイッチを閉じると一次コンデ ンサ $C_{1}$ に充電された電荷は二次コンデンサ $C_{2}$ 人移行を 開始する。このとき二次ループが開放と近似できる場合の $C_{2}$ コンデンサ電压は次式で与えられる。

$$
\begin{aligned}
V_{2}^{\prime}= & V_{10} C_{1} /\left(C_{1}+C_{2}\right)[1-\exp (-\alpha t) \\
& \times\{\cos \beta t+\alpha / \beta \sin \beta t)\}, \\
& \alpha \equiv R_{1} /\left(2 L_{1}\right), \\
& \beta \equiv\left\{\left(C_{1}+C_{2}\right) /\left(L_{1} C_{1} C_{2}\right)-\alpha^{2}\right\}^{1 / 2}
\end{aligned}
$$




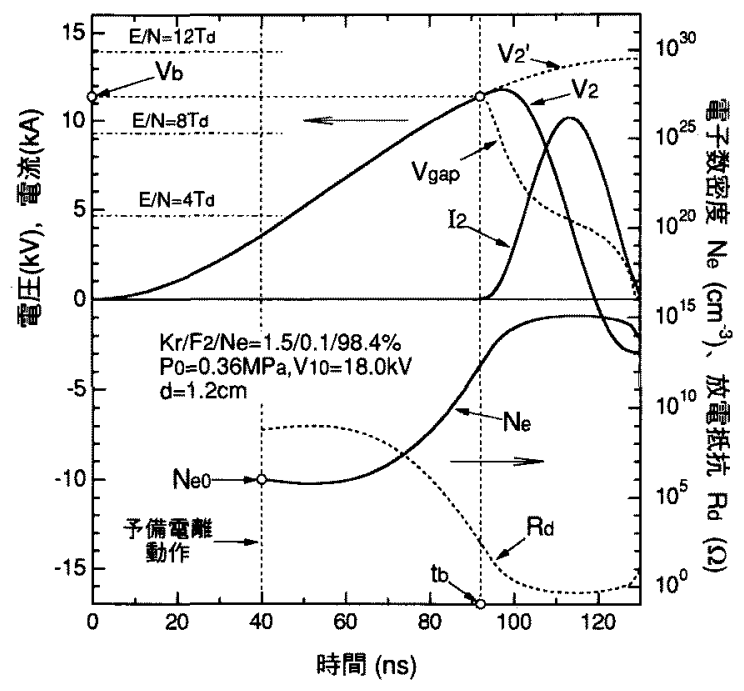

図 2 各部電圧, 電流波形, 電子数密度, 放電抵抗（計算值）

Fig. 2. Various voltage, current waveforms, electron number density, and discharge resistance (calculated value).

ここに, $V_{2}^{\prime}:$ 二次ループが開放のときの $C_{2}$ コン デンサ電圧, $V_{10}$ : $C_{1}$ コンデンサ充電電圧

(3)式に従い $V_{2}^{\prime}$ が上昇する過程に扔いて, $t=40 \mathrm{~ns}$ (実測值に対応) において予備電離を開始すると予備電離 電子は増倍を開始する。このときの放電抵抗は数百 $\mathrm{M} \Omega$ であるために二次ループは開放とみなせ，かつ放電電流 $I_{2}$ が非常に小さく $L_{2}$ での電圧降下は無視できるために $V_{2}^{\prime}$ $\fallingdotseq V_{2} \fallingdotseq V_{\text {gap }}$ である。電子增倍の結果電子数密度が約 $10^{12}$ $\mathrm{cm}^{-3}$ を超えると，(1)式による放電抵抗は $100 \Omega$ 程度と なり, 二次ループの動作が各波形に与える変化が検出可能 な值になる。すなわち，放電電流 $I_{2}$ が有限の值になり， かつそのために $C_{2}$ から放電部へ電荷が注入され $V_{2}$ は $V_{2}^{\prime}$ から離れる。更に $L_{2}$ での電圧降下のために $V_{\mathrm{gap}}$ は $V_{2}$ 上 り急激に減少する。このように，本論文では放電状態を連 続と仮定し，放電抵抗の急激な減少に伴う各部波形の変化 が検出可能となる点を放電開始点 $\left(t_{b}, V_{b}\right)$ と定義する。

本解析モデルで惊，放電開始点の前後では各部波形の変 化は連続的であり特異点をもたない。そのために，放電開 始点を定義するに注以下の近似法が考えられる。

(i) 電極間電圧 $V_{\mathrm{gap}}$ の最大点

（ii）放電電流 $I_{2}$ が一定值を超えた点

(iii） $V_{2}^{\prime}$ が $V_{2}$ と離れる，すなわち両者の差が一定值 を超光た点

これらのうち(i)，（ii）が物理的には理解しやすいと思 われる。しかし測定值との比較を考えると，放電電流 $I_{2}$ は測定時のノイズ，ジッタによりその立上りを精度良く測 定しにくく，また電極間電圧 $V_{\mathrm{gap}}$ の測定は装置の構造上 の理由から困難である。そのため, 本論文では(iii)の方法 を採用した。すなわち測定に扔いては $V_{2}^{\prime}$ を同時測定し $V_{2}$ と分離する点を放電開始点とし，計算においては $V_{2}^{\prime}$

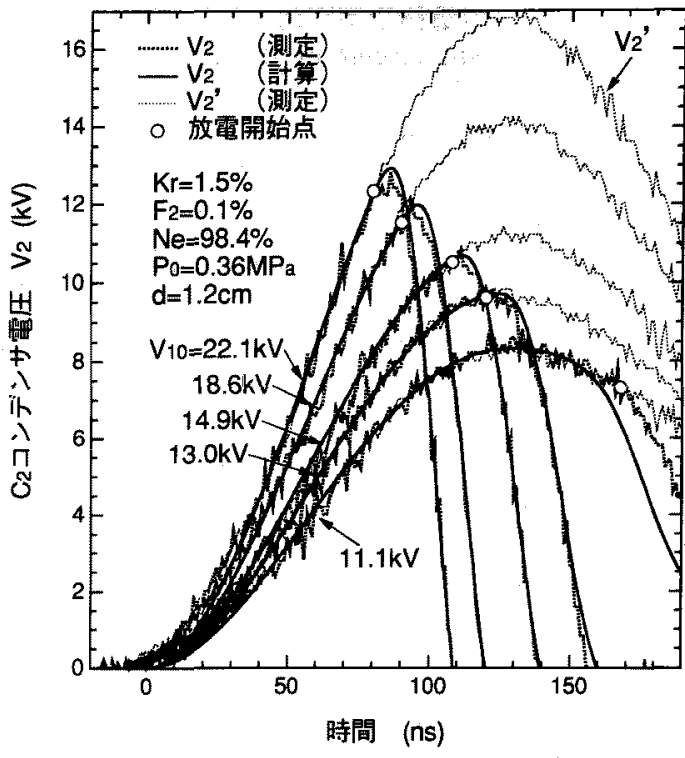

図 $3 C_{2}$ コンデンサ電圧の時間変化 Fig. 3. Time dependence of the $C_{2}$ capacitor voltage.

と $V_{2}$ との差の割合 $\left(V_{2}^{\prime}-V_{2}\right) / V_{2}^{\prime}$ が $0.5 \%$ 以上となる点を 放電開始点とした。この值には物理的意味はなく, 測定值 との比較により決定した。なお，この值を $0.1 〜 1 \%$ と変 化させたときの放電開始時間 $t_{b}$ の推定誤差は $2 \mathrm{~ns}$ 以下, 放電開始電圧 $V_{b}$ の推定誤差は $2 \%$ 以下であり, 放電開始 点の定量にはあまり影響がないことを確認したが，放電開 始前後で急激に変化する放電抵抗, 電子数密度の定量には 影響が大きい。この問題の検討は今後の課題とする。

本解析による $C_{2}$ コンデンサ電圧 $V_{2}$ の波形を測定波形 とともに図 3 に示す。パラメータは $C_{1}$ コンデンサ充電電 圧 $V_{10}$ である。 $V_{10}$ が低い場合を除き，計算波形と測定波 形治は良好な一致が見られ，本解析法の妥当性が確認され る。 $V_{10}=11.1 \mathrm{kV}$ では, 測定において放電開始点が不安 定であった。また $V_{10}=11.1 \mathrm{kV}$ のように， $V_{10}$ が低い場 合は電子増倍が遅れるために，放電開始点は $V_{2}$ の最大点 より遅れる。このような場合, 通常工学的には $V_{2}$ の最大 点を放電開始点と考皇るが(27)，本論文ではより物理的な 考察を行うために実際の放電開始点に注目した。

本解析法においては，計算に先立ち一部のパラメータを 仮定している。これらのうち， $C_{1}, C_{2}$ は設定值, $L_{1}, R_{1}$, $L_{2}$ は $V_{2}^{\prime}$ および $I_{2}$ の測定波形から推定される。また電極 間隔 $d$, 有效放電長 $L$ は設定または放電部の観察から得 られ，それぞれほほほ信頼できる值である。しかし，放電幅 $W$ と予備電離時の初期電子数密度 $N_{e 0}$ は測定が困難であ り不確定である。そこでこれらの值が放電開始電圧 $V_{b}$ に 与える影響を確認した。放電幅 $W=0.25 \sim 1.0 \mathrm{~cm}$ に対す る $V_{b}$ の推定誤差は $2 \%$ 以下, 初期電子数密度 $N_{e 0}=10^{5}$ $\sim 10^{8} \mathrm{~cm}^{-3}$ に対する $V_{b}$ の推定誤差は 7\%以下であった。 このため,これらはある程度任意に推定してよいと考え， $W$ はレーザ発振幅 $0.5 \mathrm{~cm}, N_{e 0}$ は $10^{6} \mathrm{~cm}^{-3}$ の一定值を仮 
定した。測定値との比較によると，これらの推定誤差は本 解析の範团では殆ど問題にならないことを確認した。

〈2・3〉電子增倍機構 図 $4 k \mathrm{Kr} / \mathrm{F}_{2} / \mathrm{Ne}=1.5 / 0.1 /$ $98.4 \%$ 放電開始前領域（ここでは準安定原子数密度の 存在比が $10^{-5}$ 以下の領域を考える。図 6 参照) の反応速 度定数 $k_{j}$ と電子移動度 $\mu_{e}$ を示す。 $\mathrm{Kr} の$ 直接電離反応速 度定数は $\mathrm{Ne} に$ 比べて 3 析以上大きい。これは Kr の電離 エネルギー $(13.99 \mathrm{eV})$ が $\mathrm{Ne}(20.18 \mathrm{eV})$ より小さいこ

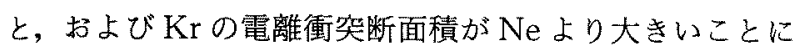
よる。また, 予備電離以後放電開始までの換算電界領域 $E / N=3 \sim 14 T_{d}\left(N:\right.$ 全ガス密度, $\left.1 T_{d}=10^{-17} \mathrm{~V} \cdot \mathrm{cm}^{2}\right)$ では，電子移動度はほぼ一定である。これは主に弾性衝突

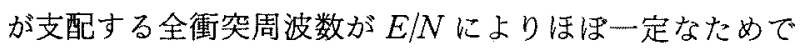
ある。これより，ガス組成が一定ならば(1)式の放電抵抗 はほ滦子数密度 $N_{e}$ に反比例することがわかる。

各種電子衝突における電子の損失エネルギーを図 5 に示 す。各特性は単位時間・単位原子数密度当たりの電子衝突 における損失エネルギーである。また全衝突損失エネルギ 一はそれらの総和であり, 単位時間・単位原子数密度当た りの電界獲得エネルギーにほほ対応する。図 5 より放電開 始前領域では $\mathrm{Kr}$ の非弾性衝突による損失が支配的であ り，また弾性衝突損失は $\mathrm{Ne}$ が支配的であること, $\mathrm{F}_{2} に$ よるエネルギー損失は直接励起衝突が支配的であることを 確認した。

図 6 に各粒子数密度および電離, 付着衝突周波数の時間 変化を示す。予備電離以後放電開始までの時間領域では, $\mathrm{Kr}^{*}, \mathrm{~F}_{2}(V)$ などの励起原子数密度は, 最大でも基底原子 $\mathrm{Kr}, \mathrm{F}_{2}(0)$ 数密度の $10^{-5}$ 以下である。そのため反応速度定

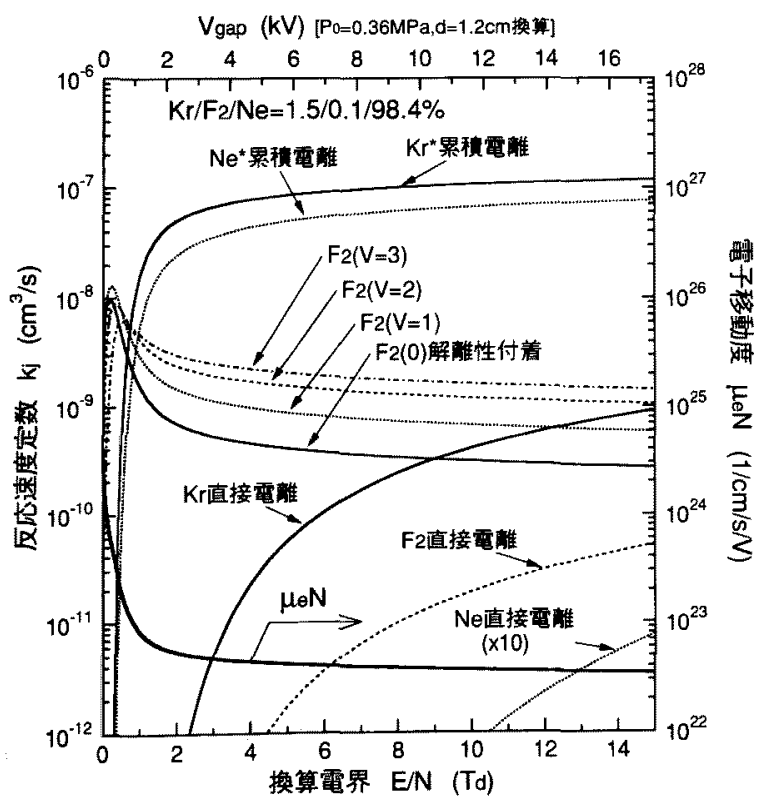

図 4 放電開始前領域の反応速度定数と 電子移動度

Fig. 4. Rate coefficients and electron mobility in the prebreakdown region.
数 $k_{j}$ と各原子数密度 $N_{j}$ の積で定義される電離, 付着衝突 周波数は, 主に基底準位の衝突反応で決定されていること が判明した。

また予備電離で発生する紫外光により $\mathrm{Kr}$ 原子が励起さ れ, その脱励起により $\mathrm{Kr}$ の準安定原子 $\mathrm{Kr}^{*}$ が生成され ると仮定すると, 累積電離 (表 $2[6]$ ) が電子増倍に影

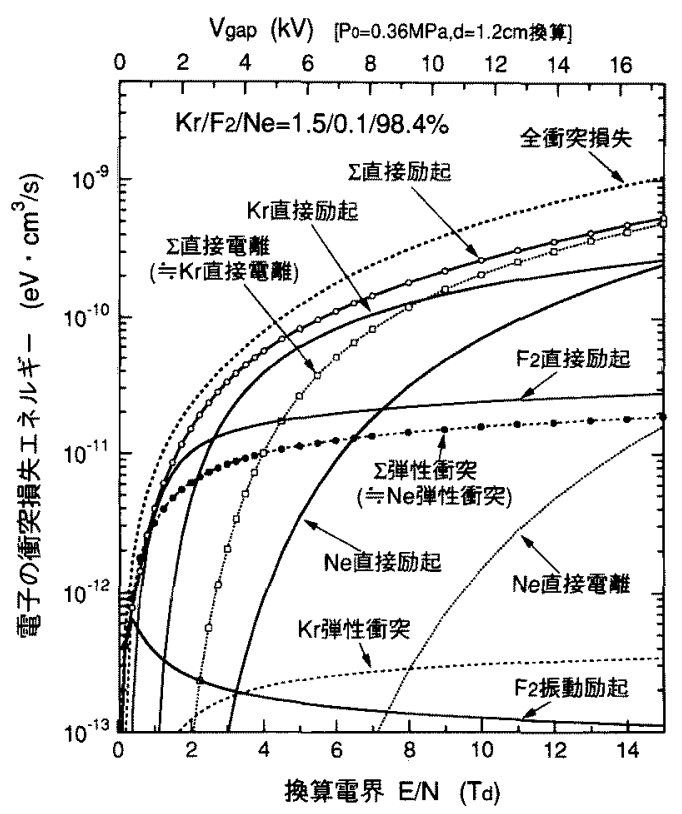

図 5 放電開始前領域の衝突損失エネルギー Fig. 5. Collision loss energies in the prebreakdown region.

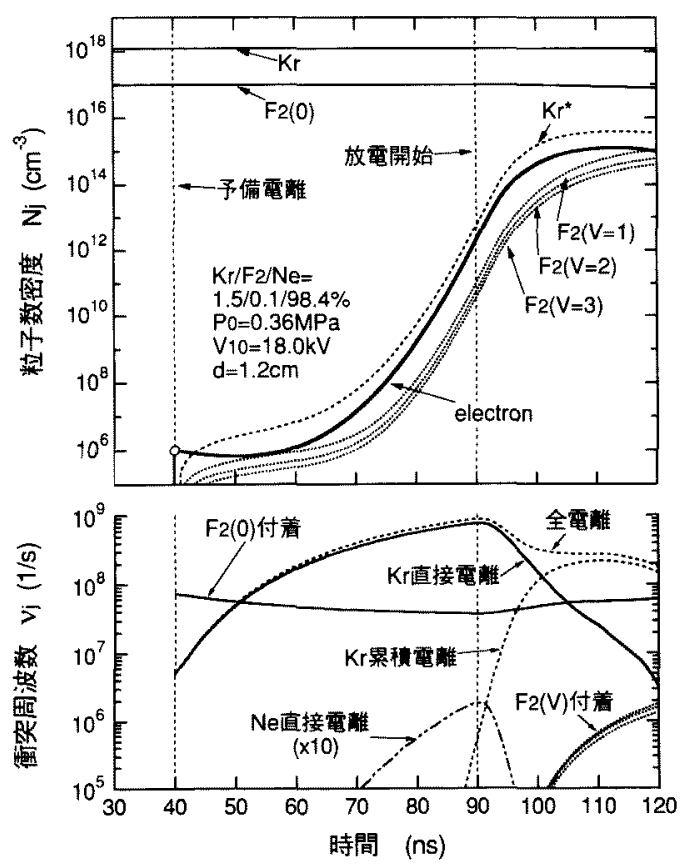

図 6 粒子数密度, 衝突周波数の時間変化 Fig. 6. Time dependence of the particle number density and collision frequencies. 
響を及漂すことも考えられる。そこで，予備電離時におけ る準安定原子数密度 $N_{\mathrm{Kr}^{*} 0}$ を変化させて図 6 に対応する計 算を行った結果, $N_{\mathrm{Kr}^{*} 0}=10^{12} \mathrm{~cm}^{-3}$ 以下であれば電子増倍 にほとんど影響がないことを確諗した。予備電離による電 子数密度が $N_{e 0}=10^{6} \mathrm{~cm}^{-3}$ 程度と考えると $N_{\mathrm{Kr}^{* 0} 0}$ の生成が $10^{12} \mathrm{~cm}^{-3}$ 以上とは考元難く，かつこの場合，放電開始点 の計算結果が剆定值と合致しないために, $N_{\mathrm{Kr} * 0}$ は $10^{12}$ $\mathrm{cm}^{-3}$ 以下と推定した。よって, 放電開始前領域では累積 電離は無視できると考えられる。更に Neの直接電離, Penning 電離, 抢よび予備電離以後の光電離はほぼ無視で きることを確認した。

すなわち, 放電開始前の電子増倍過程は, $\mathrm{Kr}$ の直接電 離（表 $2[2]$ ), $F_{2}(0)$ の解離性電子付着（表 2 [19]）が 支配的であるため，(2)式の電子普倍の式は以下に近似で きる。

$$
\begin{aligned}
d N_{e} / d t & \fallingdotseq \kappa_{\text {ion }} N_{\mathrm{Kr}} N_{e}-\kappa_{\mathrm{att}} N_{\mathrm{F}_{2}} N_{e} \\
& =\left(\kappa_{\mathrm{ion}} N_{\mathrm{Kr}}-\kappa_{\mathrm{att}} N_{\mathrm{F}_{2}}\right) N_{e} \\
& =\left(\nu_{\text {ion }}-\nu_{\mathrm{att}}\right) N_{e} \\
\nu_{\text {ton }} & \equiv \kappa_{\text {ion }} N_{\mathrm{kr}}, \quad \nu_{\mathrm{att}} \equiv \kappa_{\mathrm{att}} N_{\mathrm{F}_{2}}
\end{aligned}
$$

ここに, $\nu$ : 衝突周波数, 添字 ion, att: $\mathrm{Kr}$ 直接

電離, $\mathrm{F}_{2}(0)$ 解離性電子付着, 添字 $\mathrm{Kr}, \mathrm{F}_{2}: \mathrm{Kr}$,

$\mathrm{F}_{2}(0)$

以後の本論文の計算では, 表 2 に示した反応機構をすべ て考慮して計算を行ったが, 電子増倍機構の考察では (4) 式の衝突周波数の大小を論ずることにする。

\section{3. 放電開始特性のガス分圧, 圧力依存性}

$\langle 3 \cdot 1\rangle \mathrm{Kr}$ 分压率依存性 ${ }^{(28)}$ 図 7, 図 $8 k \mathrm{KF}_{2}=$ $0.1 \%$, 全压力 $P_{0}=0.36 \mathrm{MPa}$ の放電開始電压の Kr 分圧 率依存性を示す。ともに計算值と測定値には良好な一致が 見られる。図 7 は印加電圧 $V_{10}$ 特性である。図より $\mathrm{Kr}=$ $0.1 \sim 1.0 \%$ では $\mathrm{Kr}$ 分圧率の増加に伴い放電開始電压 $V_{b}$ は減少するが, $\mathrm{Kr}=1.5 \sim 6.0 \%$ は $\mathrm{Kr}$ 分圧率の増加に 伴い $V_{b}$ は増加する。後者の特性は满上等の報告例 ${ }^{(29)}$ と 同様の傾向である。

図 8 は放電開始時間 $t_{b}$ 特性であり, 図 3 における各放 電開始点 $\left(t_{b}, V_{b}\right)$ を結んだ特性に対応する。すなわち，図 中 $V_{b}$ と $t_{b}$ の関係は， $C_{1}$ コンデンサ印加電在 $V_{10}$ に応し て (3) 式の関係を満たす。 $\mathrm{Kr}=0.1 \sim 1.0 \%$ は $\mathrm{Kr}$ 分圧 率の増加に伴い $V_{b}$ は減少し, $\mathrm{Kr}=1.5 \sim 6.0 \%$ では $\mathrm{Kr}$ 分 圧率の增加に伴い $V_{b}$ は增加する。

更に $V_{b}$ の $\mathrm{Kr}$ 分圧率特性を図 9 示す。 $V_{10}=16 \mathrm{kV}$ 以上では $V_{b}$ は $\mathrm{Kr}=1 \%$ 付近に極小值をもつ。な掠， $V_{10}$ $=15 \mathrm{kV}$ 以下では特性は極大值をもつが, これは図 30 $V_{10}=11.1 \mathrm{kV}$ の場合と同様に電子増倍が遅れるために放 電開始点が $V_{2}$ の最大点より下がることに対応している。 これらの特性は (4) 式の衝突周波数と電子增倍の関係から 説明される。

平均電子エネルギーと電子エネルギー分布の $\mathrm{Kr}$ 分圧率
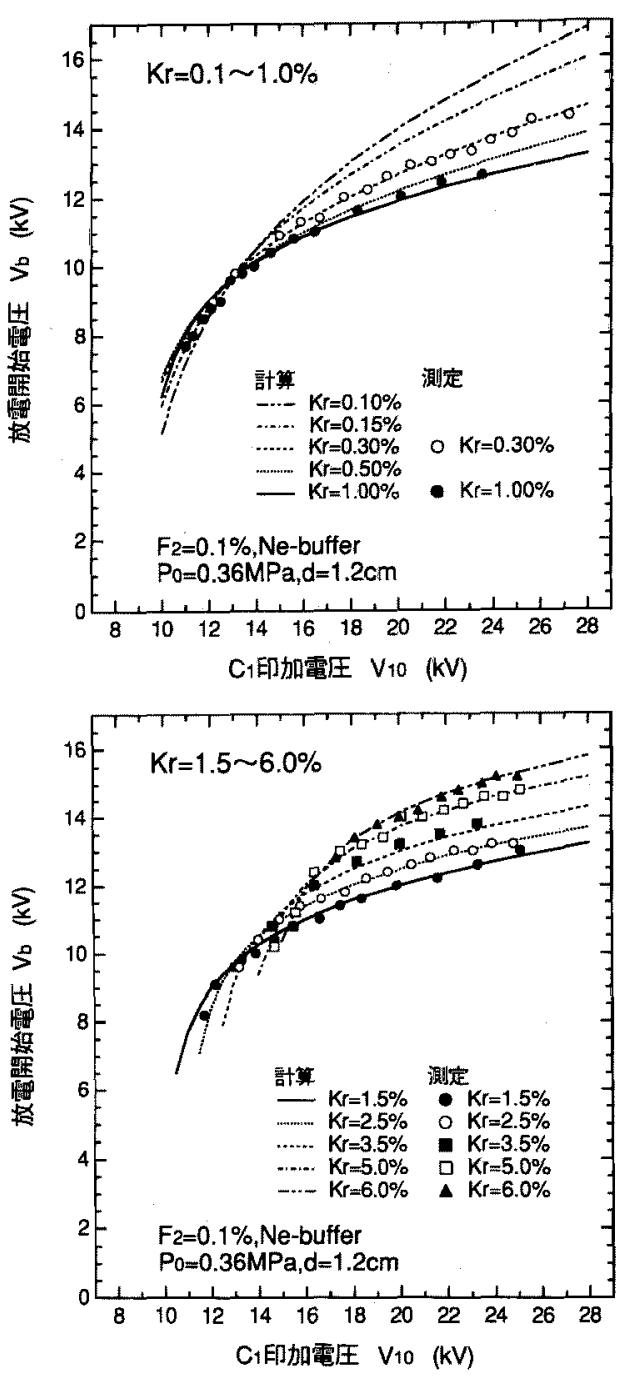

図 7 放電開始電圧の $\mathrm{Kr}$ 分圧率依存性 (1) : 印加電圧特性

Fig. 7. Dependence of the $\mathrm{Kr}$ partial pressure ratio on the breakdown voltage: (1) applied voltage characteritics.

依存性を図 10 に示す。 $\mathrm{Kr}$ 分圧率の増加に伴い平均電子 エネルギーは減少する。図 5 から確珰できるように,これ は Kr の非弾性衝突によるエネルギー損失が主因である。 そのために $\mathrm{Kr} の$ 電離エネルギー以上の電子の存在確率が 減少し, $\mathrm{Kr}$ の直接電離反応速度定数 K i n は減少する。な お, $E / N=1 T_{d}$ 以下では $\mathrm{Ne}$ の弾性衝突損失が支配的で あるために平均電子エネルギーはほとんど変化しない。

そこで, $\mathrm{Kr}$ の直接電離反応速度定数 $\kappa_{\mathrm{i} o n}, \mathrm{Kr}$ 原子数密 度 $N_{\mathrm{Kr}}, \mathrm{Kr}$ 直接電離衝架周波数 $\nu_{\text {ion }}$ の $\mathrm{Kr}$ 分圧率依存性 を図 11 に示す。非弾性衝突損失により K の増加に伴い急激に減少する。一方， $N_{\mathrm{Kr}}$ は $\mathrm{Kr}$ 分圧率に 比例する。その結果, 両者の積である $\nu_{\text {ion }}$ は $\mathrm{Kr}$ 分圧率 0.5〜 1.5\%付近に極大值をもつことになる。すなわち,こ の領域では (4)式の右辺第 1 項が大きくなり電離しやすい 状態となる。図 11 では, 参考のために解離性付着衝突周 

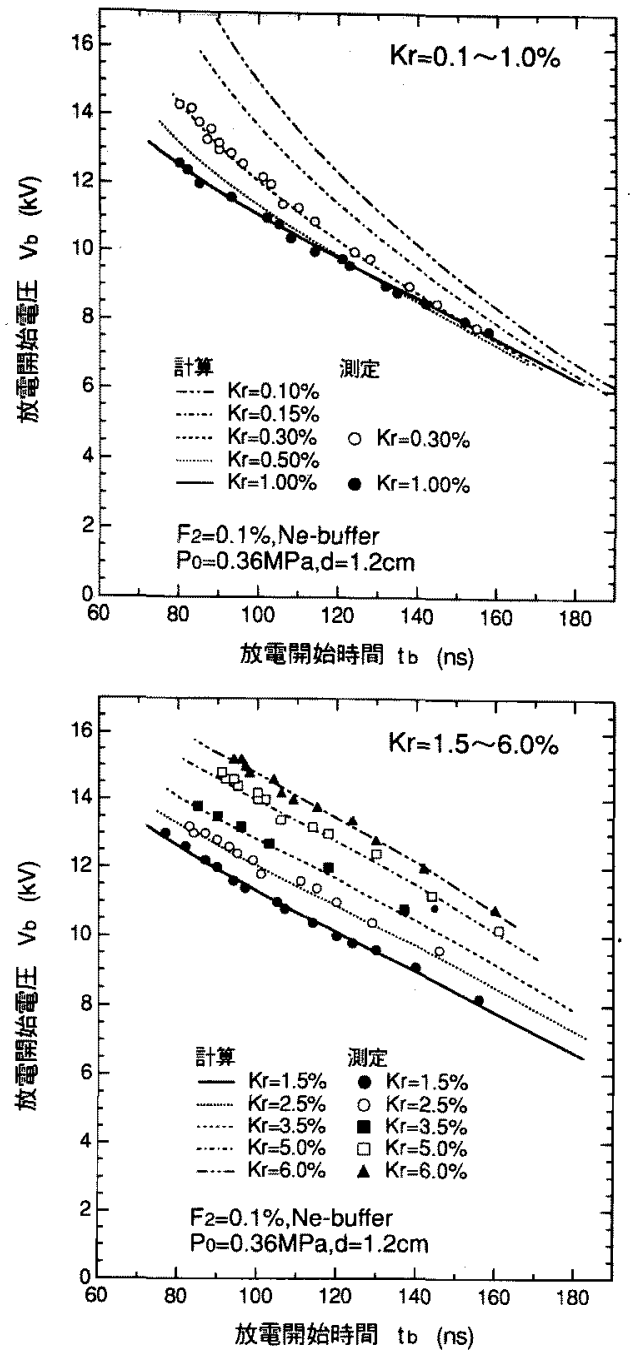

図 8 放電開始電圧の $\mathrm{Kr}$ 分圧率依存性 (2) : 放電開始時間特性

Fig. 8. Dependence of the $\mathrm{Kr}$ partial pressure ratio on the breakdown voltage: (2) breakdown time characteristics.

波数 レatt も図示したが，これは $\mathrm{Kr}$ 分圧率に対し增加する が，その值は レ 少すると $\mathrm{Ne}$ により電離衝突周波数の割合が増加するが, 本解析のガス組成の範囲では電離に対する寄与は小さいこ とがわかる。

以上を電子数密度の時間変化と対応させたものを図 12 に示す。電子増倍過程は衝突周波数の変化に対応し放電開 始特性の $\mathrm{Kr}$ 分圧率依存性が定量された。

〈3.2〉 $\mathrm{F}_{2}$ 分圧率依存性 図 13 , 図 $14 \mathrm{Kr}=1.5 \%$, 全圧力 $P_{0}=0.36 \mathrm{MPa}$ の放電開始電圧の $\mathrm{F}_{2}$ 分圧率依存性 を示す。これらも計算值と測定值には良好な一致が見られ る。図 13 は印加電圧 $V_{10}$ 特性, 図 14 注放電開始時間 $t_{b}$ 特 性である。 $\mathrm{F}_{2}$ 分圧率の増加に伴い放電開始時間 $t_{b}$ は遅延 するため放電開始電圧 $V_{b}$ は增加する。

更に $V_{b}$ の $\mathrm{F}_{2}$ 分圧率特性を図 15 に示す。 $V_{10}=16 \mathrm{kV}$

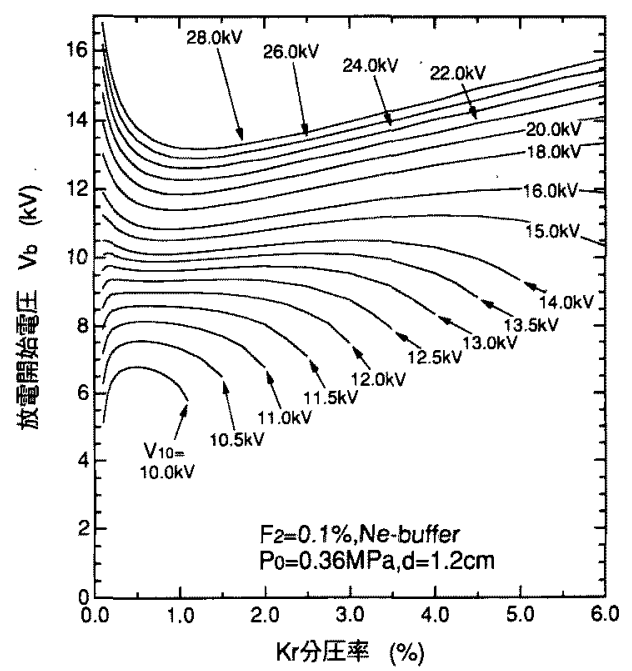

図 9 放電開始電圧の Kr 分圧率依存性 (3) : $\mathrm{Kr}$ 分圧率特性（計算值）

Fig. 9. Dependence of the $\mathrm{Kr}$ partial pressure ratio on the breakdown voltage: (3) Kr partial pressure ratio characteristics (calculated value).
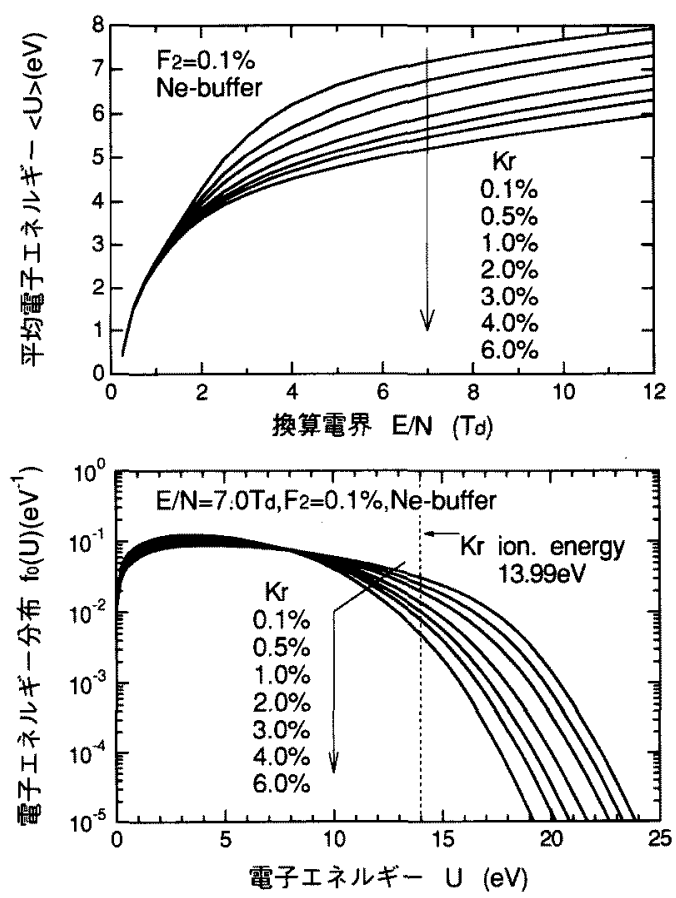

図 10 平均電子エネルギ一，電子エネルギー 分布の Kr 分圧率依存性

Fig. 10. Dependence of the $\mathrm{Kr}$ partial pressure ratio on the average electron energy and the electron energy distribution.

以上では $V_{b}$ はほぼ直線的に增加する。 $V_{10}=15 \mathrm{kV}$ 以下 では隇少するが，これは図 9 に扔ける低 $V_{10}$ 部と同様の理 由による。これらの特性も，(4) 式の衝突周波数と電子増 倍の関係から説明される。

平均電子エネルギーと電子エネルギー分布の $\mathrm{F}_{2}$ 分圧率 


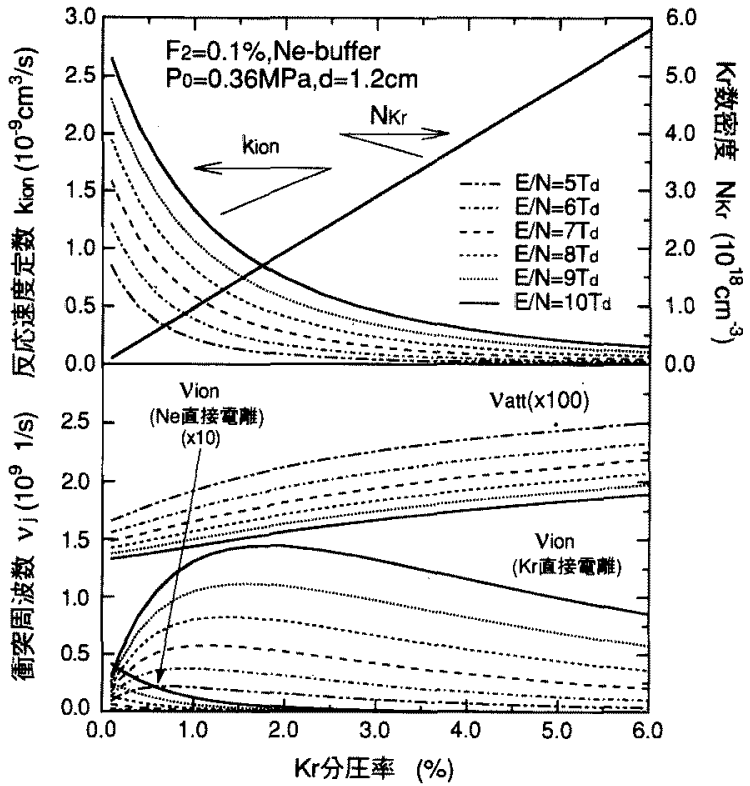

図 11 電離反応速度定数, $\mathrm{Kr}$ 数密度, 電離 付着衝突周波数の $\mathrm{Kr}$ 分圧率依存性

Fig. 11. Dependence of the $\mathrm{Kr}$ partial pressure ratio on the rate coefficient, $\mathrm{Kr}$ number density, and the collision frequencies.
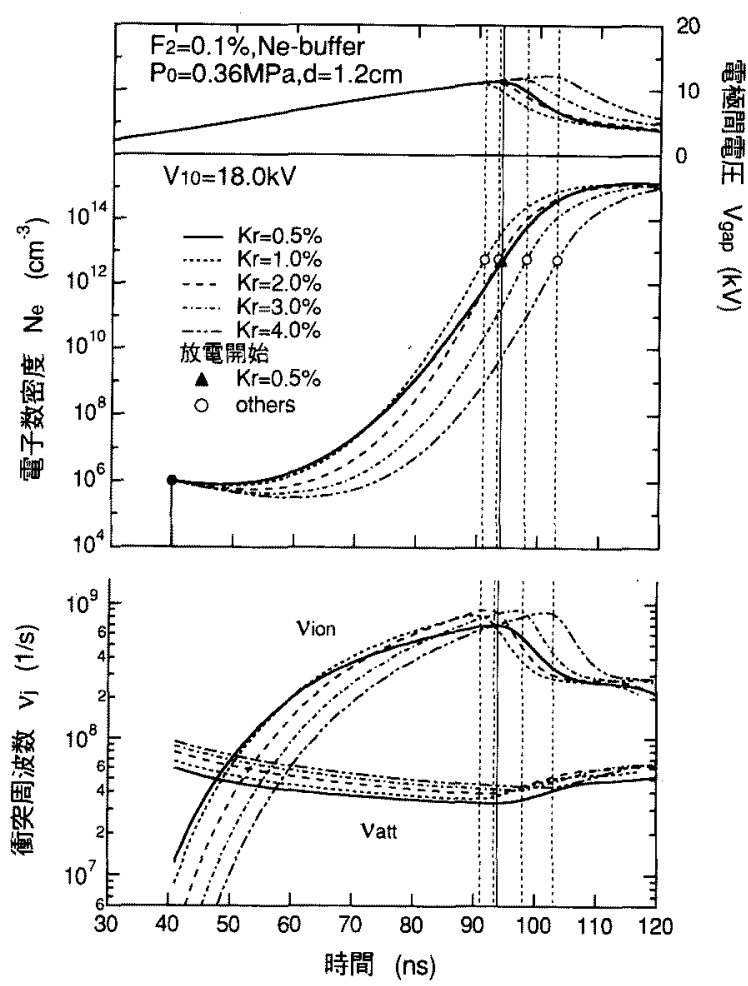

図 12 電子数密度, 衝突周波数の $\mathrm{Kr}$ 分圧率 依存性

Fig. 12. Dependence of the $\mathrm{Kr}$ partial pressure ratio on the electron number density and collision frequencies.

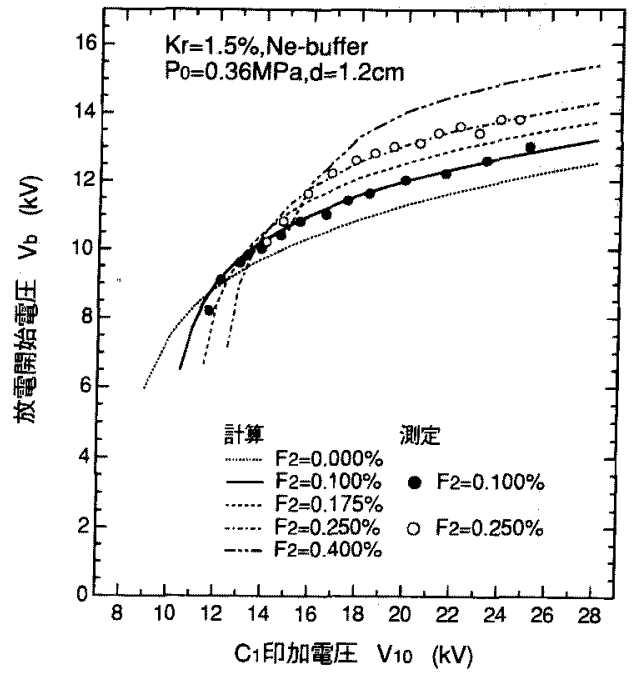

図 13 放電開始電圧 $0 \mathrm{~F}_{2}$ 分圧率依存性 (1) : 印加電圧特性

Fig. 13. Dependence of the $F_{2}$ partial pressure ratio on the breakdown voltage: (1) applied voltage characteristics.

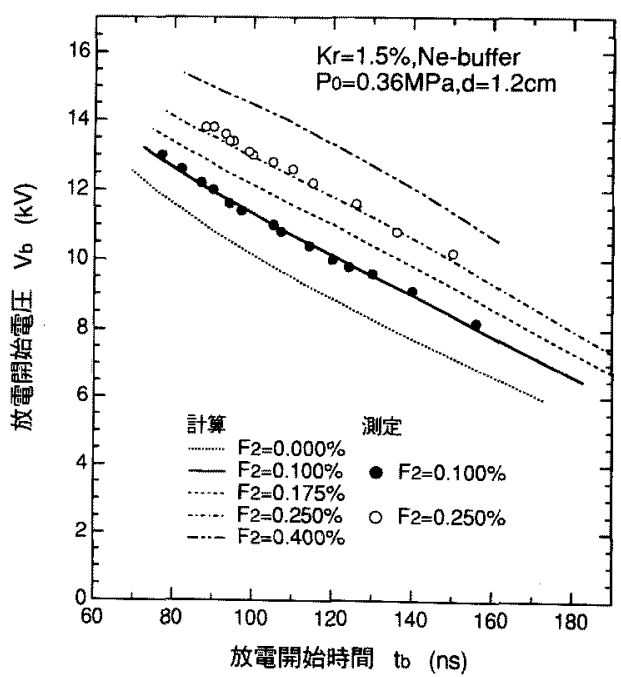

図 14 放電開始電圧 $0 F_{2}$ 分圧率依存性 $(2)$ : 放電開始時間特性

Fig. 14. Dependence of the $F_{2}$ partial pressure ratio on the breakdown voltage: (2) breakdown time characteristics.

依存性を図 16 に示す。 $\mathrm{F}_{2}$ 分圧率の増加に伴い平均電子工 ネルギーは減少する。図 5 より，これは $F_{2}$ の直接励起衝 突によるエネルギー損失が原因であることがわかる。 $\mathrm{F}_{2}$ の直接励起エネルギーは低いために低 $E / N$ 領域から $\mathrm{F}_{2}$ 分圧依存性が現われている。しかしながら，本解析のがス 組成の範囲で结, $F_{2}$ 分圧率统 $\mathrm{Kr}$ 分圧率より 1 桁程度低 いために $\mathrm{F}_{2}$ 分圧率依存性は図 10 の $\mathrm{Kr}$ 分圧率依存性より わずかである。

そこで $\mathrm{F}_{2}$ の解離性付着反応速度定数 $\kappa_{\mathrm{att}}, \mathrm{F}_{2}$ 原子数密 度 $N_{\mathrm{F}_{2}}, \mathrm{~F}_{2}$ 解離性付着衝突周波数 $\nu_{\mathrm{att}}$ の $\mathrm{F}_{2}$ 分圧率依存性 


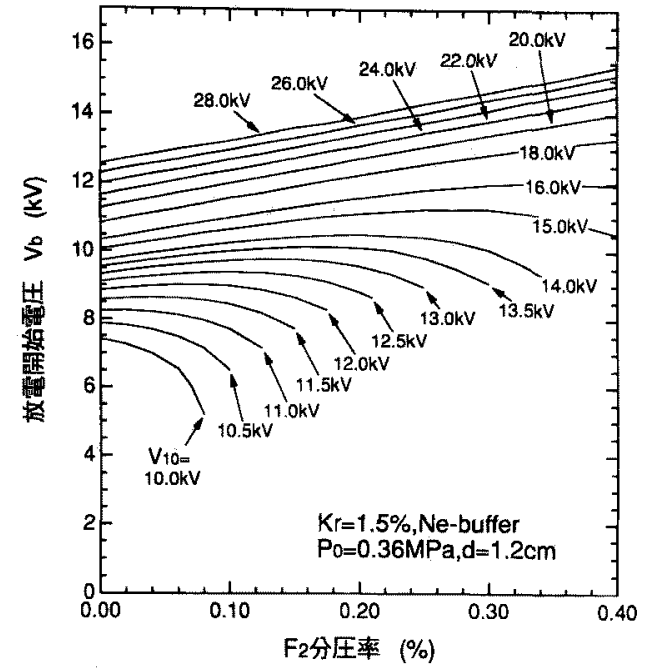

図 15 放電開始電圧の $\mathrm{F}_{2}$ 分圧率依存性 $(3)$ $: \mathrm{F}_{2}$ 分圧率特性（計算値）

Fig. 15. Dependence of the $F_{2}$ partial pressure ratio on the breakdown voltage: (3) $\mathrm{F}_{2}$ partial pressure ratio characteristics (calculated value).
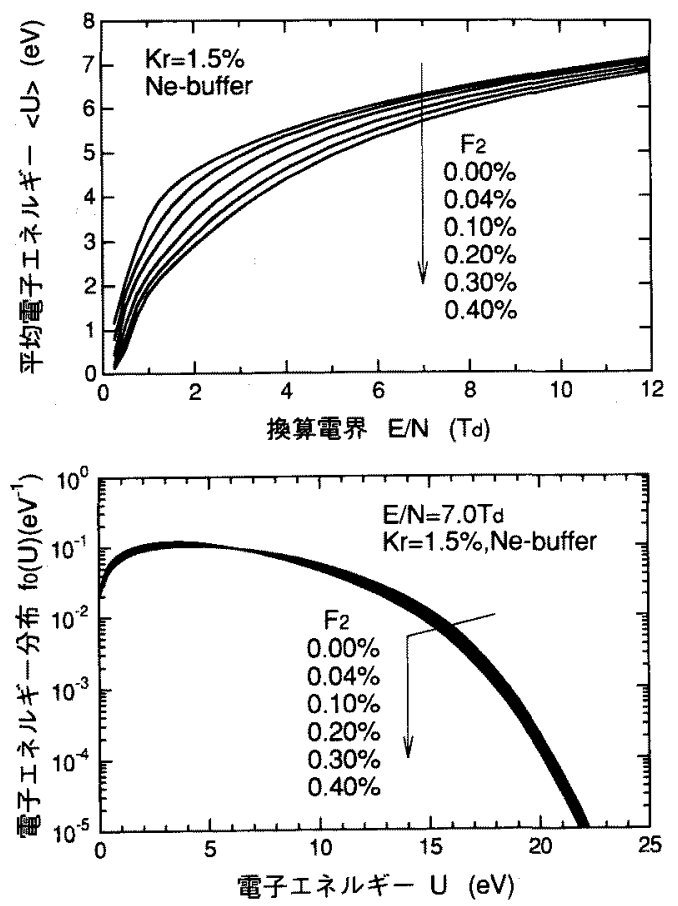

図 16 平均電子エネルギー, 電子エネルギー 分布の $F_{2}$ 分圧率依存性

Fig. 16. Dependence of the $F_{2}$ partial pressure ratio on the average electron energy and the electron energy distribution.

を図 17 に示す。Katt は $\mathrm{F}_{2}$ 分圧率の増加に伴い増加する が，その増加割合はわずかである。一方， $N_{\mathrm{F}_{2}}$ は $\mathrm{F}_{2}$ 分圧 率に比例する。その結果両者の積である $\nu_{\text {att }}$ は $\mathrm{F}_{2}$ 分圧率 に対しほほ直線的に増加する。このように $\mathrm{F}_{2}$ 分压率の増 加に伴い $\mathrm{F}_{2}$ の解離性電子付着驾増加する結果, (4) 式右

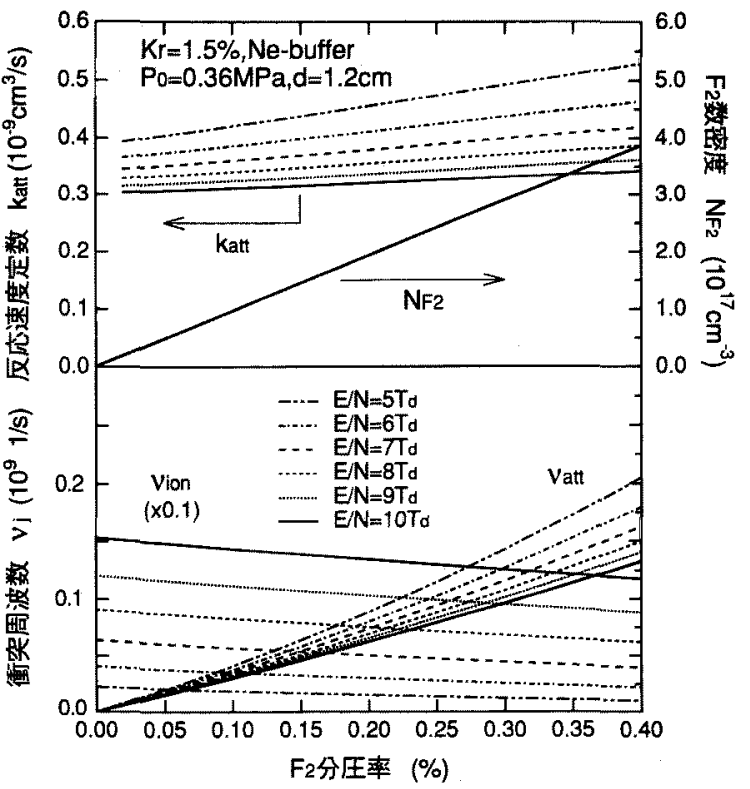

図 17 付着反応速度定数, $F_{2}$ 数密度, 電離 ・ 付着衝突周波数の $\mathrm{F}_{2}$ 分圧率依存性

Fig. 17. Dependence of the $F_{2}$ partial pressure ratio on the rate coefficient, $F_{2}$ number density, and the collision frequencies.
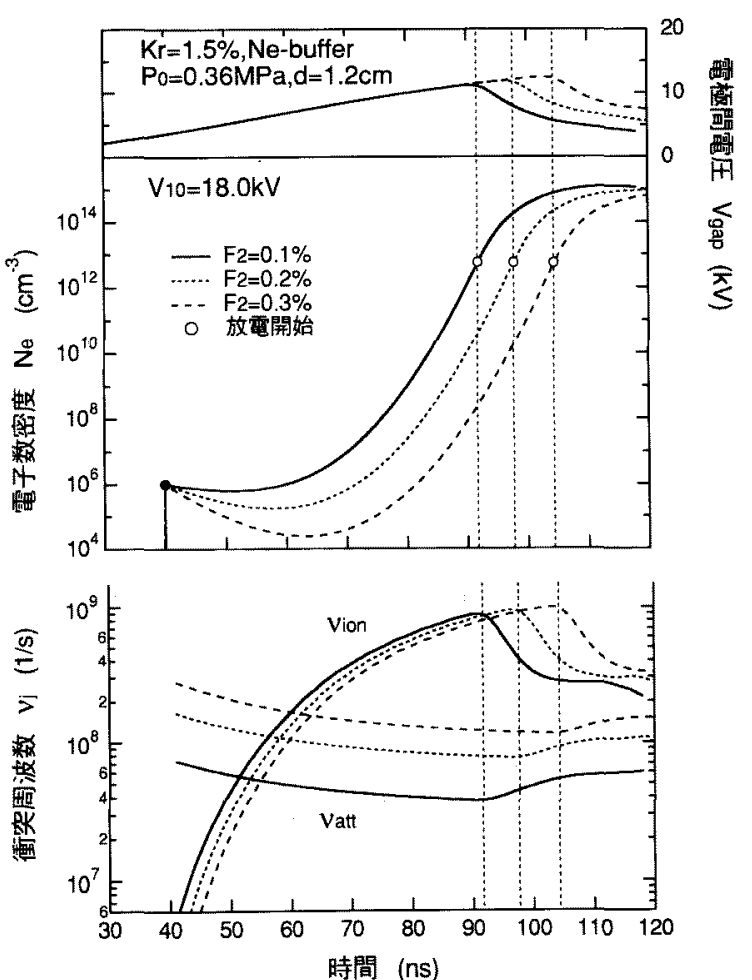

図 18 電子数密度, 衝突周波数の $\mathrm{F}_{2}$ 分圧率 依存性

Fig. 18. Dependence of the $F_{2}$ partial pressure ratio on the electron number density and collision frequencies. 
辺は隇少し電子堌倍は抑制される。図 17 では参考のため に，電離衝突周波数 䏠も図示したが，これは $\mathrm{F}_{2}$ 分圧率 の増加に伴いわずかながら減少し，電子増倍を抑制する。

以上を電子数密度の時間変化と対応させたものを図 18 に示す。電子増倍過程は衝突周波数の変化に対応し放電開 始特性の $\mathrm{F}_{2}$ 分圧率依存性が定量された。

〈3.3〉 全圧力 $\boldsymbol{P}_{0}$ 依存性 図 19, 図 $20 \mathrm{Kr}=1.5 \%$, $\mathrm{F}_{2}=0.1 \%, \mathrm{Ne}=98.4 \%$ 放電開始電圧の全圧力 $P_{0}$ 依存 性を示す。これらも計算値と测定值には良好な一致が見ら れる。図 19 は印加電圧 $V_{10}$ 特性, 図 20 は放電開始時間 $t_{b}$

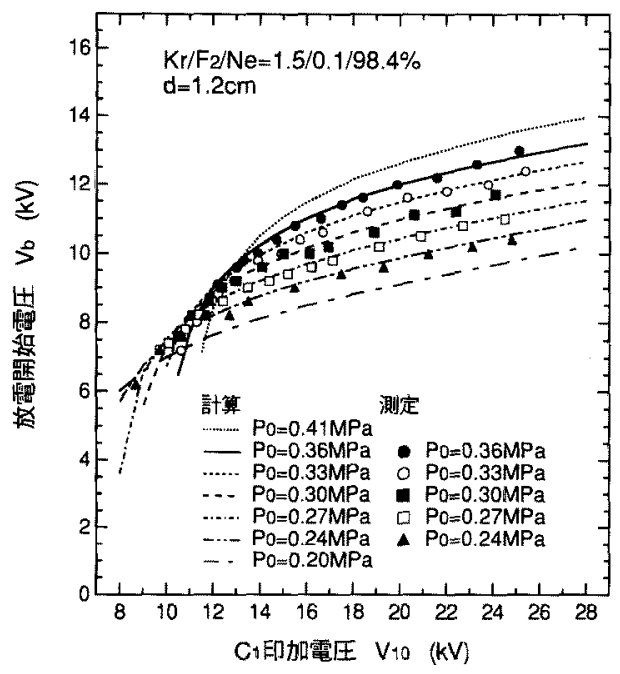

図 19 放電開始電圧の全圧力依存性 (1) ：印加電死特性

Fig. 19. Dependence of the total pressure on the breakdown voltage: (1) applied voltage characteristics.

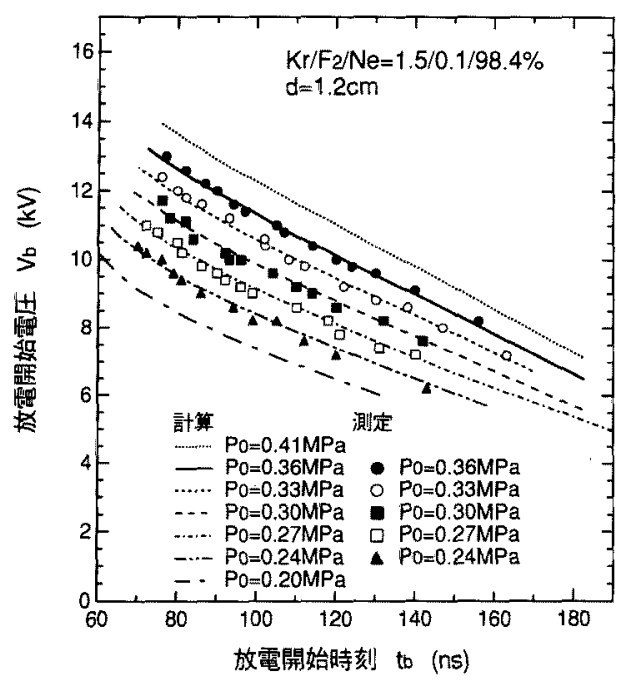

図 20 放電開始電王の全圧力依存性 (2) : 放電開始時間特性

Fig. 20. Dependence of the total pressure on the breakdown voltage: (2) breakdown time characteristics.
特性である。 $P_{0}$ の増加に伴い放電開始時間 $t_{b}$ は遅延する ため放電開始電圧 $V_{b}$ は増加する。

更に $V_{b}$ の $P_{0}$ 特性を図 21 に示す。 $V_{10}=18 \mathrm{kV}$ 以上で は $V_{b}$ はほほ直線的に堌加する。 $V_{10}=13 \mathrm{kV}$ 以下では減 少するが，これは図 9 における $V_{10}$ 部と同様の理由によ る。これらの特性も (4) 式の衝突周波数と電子増倍の関係 から説明される。

この場合，ガス組成比が一定のため同じ換算電界 $E / N$ に対する平均電子エネルギー，反応速度定数の值は同じで ある。しかし同じ電極間電压 $V_{\text {gap }}$ に対する $E / N$ は $P_{0}$ に 反比例する。図 4 に示したように, $\mathrm{Kr}$ 直接電離の反応速 度定数は， $E / N$ に対し急激な変化をするために， $P_{0}$ の增 加に伴いK $\mathrm{ion}$ は急激に隇少する。一方, $\mathrm{Kr}$ 原子数密度

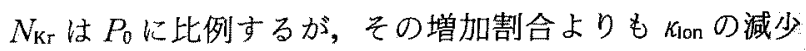
割合のほうが大きいため，結果として 対して減少し電子増倍は抑制される。以上を電子数密度の 時間変化と対応させたものを図 22 に示す。電子増倍過程 は衝突周波数の変化に対応し, 放電開始特性の全圧力依存 性が定量された。

な㧍， $P_{0}$ をより低下させれば， $N_{\mathrm{Kr}}$ の減少により々 減少し放電開始電压は增加することが予測される。これ は, Paschen 極小值の左側に対応するような低気圧領域 で現われると予測され，エキシマレーザ発振の領域からは ずれるために解析対象としなかった。

\section{〈3・4〉 放電開始点における電子数密度, 放電抵抗}

図 12, 図 18, 図 22 では, 放電開始点に扔ける電子数密 度 $N_{e}$ を丸印で図示している。これらは条件によらず 4.9 5.5 × $10^{12} \mathrm{~cm}^{-3}$ の範囲にあり，功とのときの放電

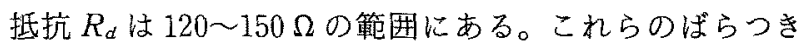
は, 第 2 章で定義した放電開始点の定量法に伴う数值計算

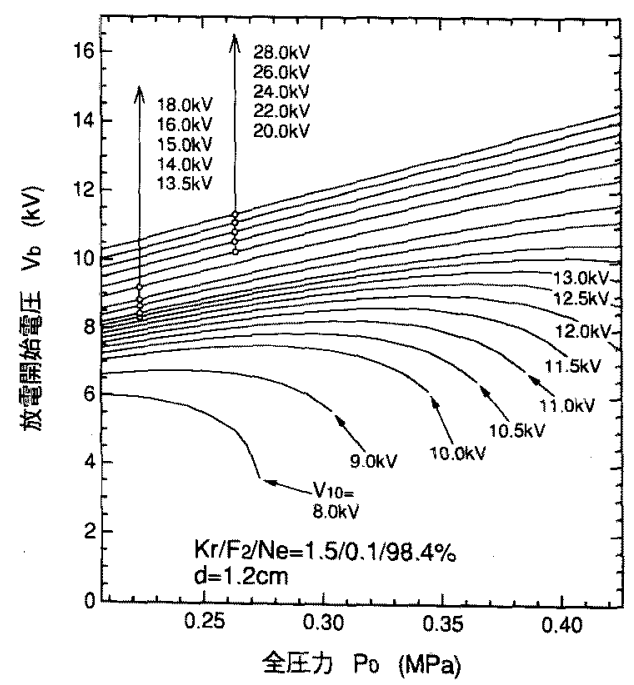

図 21 放電開始電圧の全圧力依存性 (3) : 全圧力特性（計算值）

Fig. 21. Dependence of the total pressure on the breakdown voltage: (3) total pressure characteristics (calculated value). 

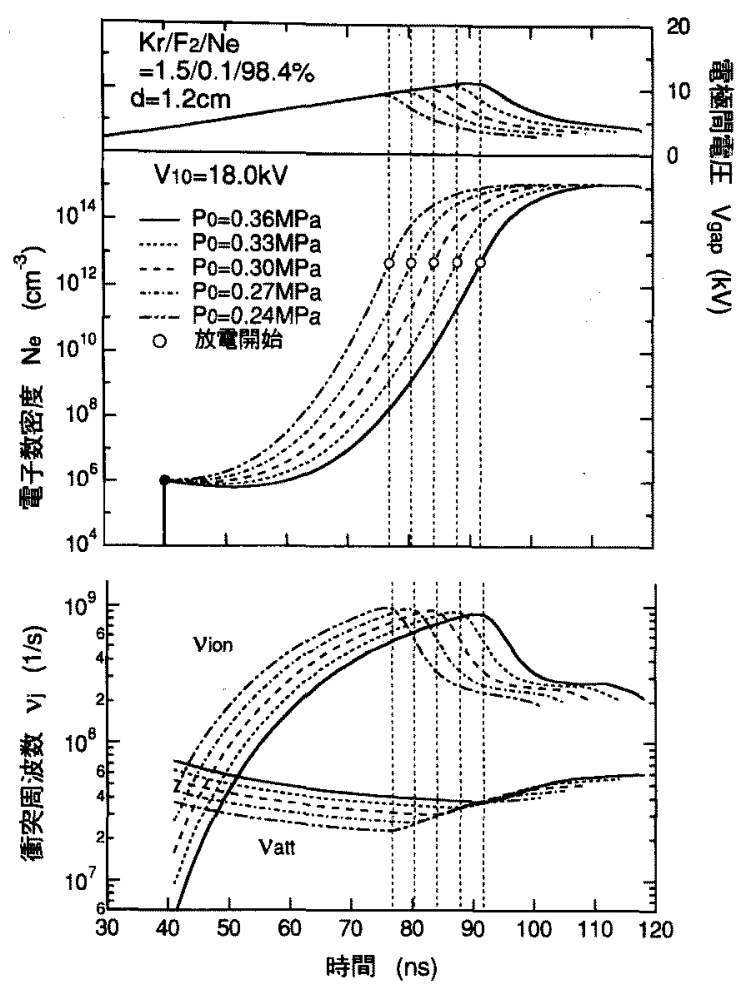

园 22 電子数密度, 衝突周波数の全圧力依存性 Fig. 22. Dependence of the total pressure on the electron number density and collision frequencies.

の誤差を考えるとほぼ一定と推定できる。

本解析では, 放電開始点を図 1 の等価回路の二次ループ が開放とみなせるか否かで判定している。そのため，放電 開始点に扔ける放電抵抗の值は, 回路各部のインピーダン スとの大小により定量されうると考えられる。本論では表 1 の回路定数を一定としているが, 回路定数および電極間 隔依存性を含めた解析㹥今後の興味深い課題である。

また，放電開始時における電子数密度が一定となること は, 以下の行村ら ${ }^{(4)(5)}$ の放電開始条件,

$\int_{0}^{5 c}(\alpha-\eta) d x=$ const.

ここに, $\zeta_{c}$ : 電子なだれの進展長, $\alpha$ : 電離係数,

$\eta:$ 付着係数, $x$ : 陰極から陽極方向への座標

と定性的に一致する概念と思われ, 本解析法との比較も今 後の課題である。

\section{4. まと め}

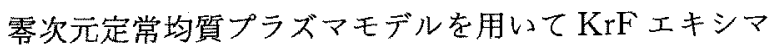
レーザガス中の放電開始特性を解析し, 以下の知見を得 た。

（1）電子数密度の増加に伴う放電抵抗の急激な減少を 定量することにより，放電開始点を定量化した。結果は測 定值と良好に一致し, 予備電離で制御された放電開始の機 構の解明と放電開始点の予測が可能となった。

（2）放電開始電圧は, $\mathrm{Kr}$ 分圧率の増加に伴い極小値
をもつことが判明した。これは $\mathrm{Kr}$ 原子数密度と電離反応 速度定数の積, すな⿰七ち電離衝突周波数の変化と対応す る。 $\mathrm{Kr}$ 分圧率が $1.0 \%$ 以下では $\mathrm{Kr}$ 原子数密度の減少を 起因として $\mathrm{Kr}$ 分圧率の減少に伴い放電開始電圧は増加 し, $\mathrm{Kr}$ 分圧率が $1.5 \%$ 以上では電離反応速度定数の減少 を起因として $\mathrm{Kr}$ 分圧率の増加に伴い放電開始電圧は増加 する。

（3）放電開始電圧は $\mathrm{F}_{2}$ 分圧率の増加に伴い増加する ことを確認した。これは解離性電子付着の増加により, 電 子増倍が抑制されるためである。

（4）放電開始電圧は全圧力の増加に伴い増加すること を確認した。これは換算電界 $E / N$ の減少により, 電子增 倍が抑制されるためである。

(平成 7 年 4 月 28 日受付, 同 7 年 7 月 19 日再受付)

\section{文献}

(1) M. M. Turner \& P. W. Smith : IEEE Trans. Plasma Sci., 19, No. 2, 350 (1991)

(2) M. Bähr, W. Bötticher \& S. Choroba: ibid., 19, No. 2, 369 (1991)

(3) H. Lück, D. Loffhagen \& W. Bötticher: Appl. Phys. B, 58, 123 (1994)

（4）行村 - 㕠田 ・内藤・加藤・ 11北・五井野：電学論 A, 109, 9 (平元 -1)

（5）行村・川上・人見: 同上 A, 111，291（平 3-4)

(6) H. Hokazono, K. Midorikawa, M. Obara \& T. Fujioka: $J$. Appl. Phys., 56, No. 3, 680 690 (1984)

（7）水波・前田・内野・下村・宫副：レーザ研究, 9, No. 5, 52 (昭 56)

(8) M. Maeda, A. Takahashi, T. Mizunami \& Y. Miyazoe: Japan. J. Appl. Phys., 21, No. 8, 1161 (1982)

（9）川上·行村：電気学会放電研資, ED-91-79, 21 (平 3)

(10) F. Kannari, M. Obara \& T. Fujioka: J. Appl. Phys., 57, No. 9, 4309 (1985)

(11) Y.W. Lee, E. Matsui, F. Kannari \& M. Obara: IEEE, J Quant. Elect., 25, No. 9, 2053 (1989)

(12) F. Kannari, W. D. Kimura \& J. J. Ewing: J. Appl. Phys., 68, No. $6,15,2615$ (1990)

(13) 狭間: レーザ研究，22，No，2，22（平 6)

(14) T. Y.Chang: Rev. Sci. Instrum, 44, 405 (1973)

（15）永井・春田・传藤・井上：レーザ学会研報, RTM-91-26，15（平 3)

(16) 斉藤・佐藤・藤川・井上・春田：電気学会放電研資, ED-94-63, 59 (平 6 )

(17) H. Akashi, Y. Sakai \& H. Tagashira: J. Phys. D : Appl. Phys., 27, 1097 (1994)

（18）例无ば，B.N.Chapman（岡本幸雄訳）：プラズマプロセシング

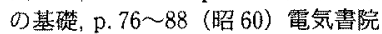

(19）林：日本学術振與会プラズマ材料科学第 153 委員会編, プラズマ 材料科学ハンドブック, 付録 3 (平 4) オーム社

(20) M. Hayashi : J. Phys. D : Appl. Phys., 15, 1411 (1982)

(21) D. F. Register, S. Trajmar \& G. Steffensen: Phys. Rev. A, 29, No. 4, 1793 (1984)

(22) N. J. Mason \& W. R. Newell : J. Phys. B, At. Mol. Phys., 20, 1357 (1987)

(23) H. A. Hyman: "brief reports", Phys. Rev. A, 24, No. 2, 1094 (1981)

(24) D. Ton-That \& M. R. Flannery: Phys. Rev. A, 15, No. 2, 517 (1977)

(25) M. Hayashi \& T. Nimura: J. Appl. Phys., 54, No. 9, 4879 (1983)

(26) J. N. Barsley \& J. M. Wadehra : J. Chem. Phys., 78, No. 12, 15, 7227 (1983)

（27）例之ば，大木正路：高電圧工学, p. 81 (平 4) 槙書店

（28）盛藤・佐藤・殖栗：第 42 回春応物学会講演予稿䈎，No. 1, 30p$\mathrm{TF}-2,32$ (平 7 )

（29）溝上・行村：電気学会放電研資, ED-94-18, 99（平 6) 
斉 藤 善 夫（正員）1991 年 3 月北海道大学大学院工学研究 科電子工学専攻博士課程修了。同年 4 月三菱電 機(株)入社。現在, 同先端技術総合研究所にて エキシマレーザの開発に従事。工学博士。レー ザ学会, 応用物理学会会員。

佐 藤 行 雄 (正員) 1980 年慶應義塾大学大学院工学研究科 電気工学専攻修士課程修了。同年 4 月三菱電機 (株) 入社。現在, 同先端技術総合研究所勤務。 大出力 $\mathrm{CO}_{2}$ レーザ, エキシマレーザ, 銅蒸気レ ーザの研究開発に従事。1991 年レーザ学会奨励 賞受賞。レーザ学会, 応用物理学会会員。
殖 栗 成 夫（正員） 1974 年 3 月東京大学大学院工学系研究 科電気工学専攻修士課程修了。同年 4 月三菱電 機(株)入社。アーク溶接機など放電応用装置, 大出カレーザの開発を経て, 現在, 同生産技術 センターにて電子回路基板の高密度実装技術の 開発に従事。工学博士。レーザ学会, 応用物理 学会会員。

$\& \&$

$\& \infty \&$ 